\title{
Gender on Board and the Impact to Firm Performance through Innovation as Mediating Variable: Evidence from Indonesian non-Financial Firms
}

\author{
Zahwaril Hasina $1^{*}$, Yustrida Bernawati ${ }^{2}$ \\ 1,2Department of Accounting, Economic and Business Faculty, Universitas Airlangga, Indonesia \\ *Corresponding Author: zahwaril.hasina-2018@feb.unair.ac.id
}

\begin{abstract}
This study examines the effect of gender on board on firm performance in Indonesia through innovation as mediation. The independent, dependent, and mediating variable used in this research is the gender of the board of directors, firm performance, and innovation. This analysis uses Indonesian non-financial firms that perform any innovation activities and are listed on the Indonesian Stock Exchange in 2009-2019 as our sample. The method used in this study is the quantitative method and processed by using SPSS tools to test the hypothesis. The results showed that gender onboard has no effect on firm performance directly but positively affects innovation. Meanwhile, innovation has a positive effect on firm performance. Then gender on board has a positive impact on the firm performance through innovation as the mediation variable. The novelty of this research is to add an innovation variable to clarify the effect of gender on board to the firm performance. This research can be used to consider companies and other policymakers to determine the board in the company.
\end{abstract}

Keywords: Gender on board; firm performance; innovation; upper echelon theory; resource-based view theory

\section{INTRODUCTION}

A firm is founded with the main aim to give shareholders welfare. Shareholders' welfare will be reflected by a firm performance representing the firm's ability to generate profits on its assets and equity. Therefore, firm performance becomes the attention of investors as well as the company's main focus. That's why firms need any policies and definite efforts to achieve a good corporate performance. Thus, the firm needs human resources in the organization to make decisions about efforts to progress the company's company.

Directors can conduct decision-making to generate a good firm performance with certain characteristics. This is in line with Upper Echelon Theory, explaining that directors' experience, values, and characteristics will affect how the directors interpret a situation that 
can affect their decisions (Hambrick and Mason 1984). Leaders have their characteristics that can form a perception that affects the decisions and actions of directors related to the company and impact firm performance. Therefore, the characteristics of the directors should be considered in the process of selecting a director. Thus, they can place directors who have the right character, such as dynamic, and able to bring the firm to achieve good performance.

The characteristics in this research are about the characteristics inherent in a CEO. Characteristics of a person can be divided into several parts. Kaur and Singh (2019) distinguished two types of characteristics, such as demographic characteristics and professional characteristics. Demographic characteristics are education level, gender, and nationality, while professional characteristics or job-related characteristics are tenures, share ownership, and directorship.

This research focuses on one of the characteristics of directors named gender because gender is an interesting topic for researchers. Besides, gender becomes the most important factor compared to other characteristics at this time, because the presence of women in the top management and the board of directors is still very few, even though we already know that gender really determines how a leader will provide any inputs and lead for the progress of the company. It is not uncommon for men and women to have different priorities in decision-making. Gender bias causes women to have abilities that are not better than men. It causes women to be underestimated and less trusted, especially in management effectiveness and business negotiations (Jadiyappa et al., 2019). However, the gender gap is currently fading due to gender equality. Several countries, including Indonesia, have conducted gender equality.

Indonesia has made various efforts to eliminate gender inequality by eliminating all forms of discrimination against women through Law No. 7 1984. Then, in 2000, there was a Presidential Instruction No. 9 on the year 2000 concerning Pengarusutamaan Gender dalam Pembangunan. The Women In Business 2020 stated that Indonesia is in fourth place as a country with the highest number of women in senior management positions. The presence of women has been evenly distributed and mostly in the positions such as chief finance officer (CFO), human resource director, and chief information officer (CIO). The issue of gender equality attracts the author to examine the impact of the presence of women on the board of directors as decision-makers, which can have an impact on firm performance in the future.

Gender affects how to interpret a problem and how to deal with the problem. The presence of women in an organization can provide a separate point of view and the distinctive characteristics of each gender. Besides, that gender differences become a determinant of leadership abilities. Women and men have different experiences and backgrounds that influence how they meet principal's demands (Sofian and Wijaya 2020). Based on the upper echelon theory, to be able to understand and predict a company both regarding performance and strategy selection, it is necessary to pay attention and understand the characteristics of the firm's leadership, such as the presence of women on the board of directors (Hambrick and Mason 1984). Women have a better ability to make relationships with the external environment, knowledge of consumers, markets, company needs, and decisions. It makes women have better decisions than men (Goodstein et al. 1994; Arfken et al. 2004; Smith et al. 2006; Post and Byron 2015). Alisjahabana, in her book entitled Perempuan Pemimpin, also emphasizes that women have a leadership style that 
tends to be participatory, gives high priority to human resource development, and also cares about details. The leadership style possessed by women is very suitable in the current innovation era.

Research on the presence of women on the board of directors has been widely conducted. Duppati et al. (2020) examined the effect of female directors on company performance using a proxy for the percentage of female directors compared to male directors and using the proxies for return on assets (ROA) and Tobin's $Q$ for firm performance. Duppati et al. (2020) found that an increase in the number of women has a positive impact on company performance. Naseem et al. (2019) and Tleubayev et al. (2020) also found the positive effect of female directors on company performance by using the proxies of return on assets and return on sales to measure company performance. Yet, several researchers have found different results. Oldford et al. (2020) and Kaur and Singh (2019) found that female directors have a negative impact on firm performance. Meanwhile, (Amran et al. (2014)), Dale-Olsen et al. (2012), Shukeri et al. (2012), Rose (2007) did not find a significant effect between female directors and company performance.

Based on the results of previous research, there was still a research gap regarding the effect of board gender on firm performance with inconsistent results. This inconsistency was considered to be due to confounding variables. The process theory explains that an independent variable is considered an element that only affects the dependent variable. However, the independent variable did not sufficiently present the result. It required the involvement of other variables when combined, and they can provide a causal explanation (Markus and Robey 1988).

Furthermore, the gender of the board of directors is not sufficient to affect firm performance. Therefore, there are confounding variables that need to be explored to find evidence of a more consistent effect between the gender of directors on company performance. Further, this research used control variables such as leverage, the board size, firm size, and firm age.

The novelty of this research is to develop the research conducted by Kaur and Singh (2019) by adding a variable, is the innovation variable, as a mediation. This research chose innovation as mediation because innovation is an effort for any company to gain a competitive advantage and stay in business. However, unfortunately, it is still rarely done in Indonesia, especially. The effect of innovation needs to be tested empirically because it is a firm's effort to improve performance through competitive advantages resulting from the innovation process. Previous research has not yet considered the contribution of innovation to the effect of board gender on company performance.

Innovation can improve firm performance. As an effort to create a product (Kotler dan Keller 2009), innovation can obtain exploratory and exploitative learning that can open opportunities and get competitive advantages to increase firm performance (Liu 2017). As mentioned by Ruiqi et al. (2017), innovation can be an effort to improve firm performance through the creation of new products. Innovation requires costs that can be called company investment because, with innovation, the firm is able to create new and superior products that can give the firm a competitive advantage. Thus, the firm can increase profits and improve its performance (Tebourbi et al. 2020).

Based on the explanation described above, there is an assumption that innovation is a variable that mediates between the effects of CEO characteristics on firm performance. 
So, this research aims to obtain empirical evidence regarding the effect of gender on board to firm performance and further examine the effect of innovation on this relationship. This research can be used to consider companies and other policymakers to determine the board in the company. This research used a research sample of non-financial companies listed on the Indonesia Stock Exchange and conducted research and development (R\&D) activities in 2008-2019. To test the hypothesis of this study used multiple linear regression.

This research contains (1) background, (2) hypotheses development, (3) method, data, and analysis, (4) result, (5) discussion, and also (6) conclusion, limitations, and the suggestion that are explained as follows.

\section{HYPOTHESES DEVELOPMENT}

Upper echelon theory associates the characteristics of leaders with company performance and makes the characteristics of leaders a reference for observing company performance. The upper echelon theory states that a leader has a personality that can affect the interpretation of the conditions experienced, thereby influencing the choice of policy for the company. Therefore, the way to understand a company is to understand the characteristics of the leader (Hambrick 2007). The activities carried out are more difficult, such as determining the company's strategic plan, illustrating that individual characteristics such as gender, age, and educational background are very important to be considered in selecting a CEO (Kaur and Singh 2019).

The board of directors also has a natural limitation as an individual. Behavioral factors such as rational limitations, goals that are contrary to company goals, and various personal aspirations are believed to affect the CEO in making strategic choices that will ultimately affect the company's performance (Nielsen 2010).

\section{The Effect of Gender of Directors toward Innovation}

The presence of women on the board of directors can increase the firm's innovation activities. Innovation is an activity that requires new and creative ideas. Women have different ideas, perspectives, and ways of making decisions than men. Women are also more conscientious and have better diligence (Adams and Ferreira 2009) to oversee the innovation process. Female directors have a competitive advantage from a broader base of knowledge and creativity (Laguir and Den Besten 2016), resulting in more diverse and unbiased information, quality of discussion, and strategic alternatives (Bilimoria 2006; Eagly 2005; Post and Byron 2015). Hence, the presence of women increases the diversity of the board, which can improve the quality of decision-making, and the creativity of women can increase innovation (Torchia et al., 2018; Campbell and Mínguez-Vera, 2008).

Previous research has supported the argument that the presence of women has a positive effect on innovation. (Atallah et al. 2020) found that innovation reflected in the level of research and development increased with an increase in the number of female directors. Torchia et al. (2018) and Hernández-Lara and Gonzales-Bustos (2020) also found the positive effect of having women on the innovation board. Furthermore, the compiled hypothesis is as follows:

\section{$\mathrm{H}_{1}$ : female directors affect positively toward innovation}

\section{The Effect of Innovation toward Firm Performance}

Firm innovation is a company's effort to create products and services (Kotler and Keller 2009) through the research and development (R\&D) process. Innovation is also a 
way for a firm to create and introduce new products, processes, and organizational systems (Zahra and Garvis 2000). Corporate innovation has a positive effect on firm performance. Innovation activities can't only produce a new product or process but also can increase the company's knowledge and experience that becomes the company's resources.

Based on a resource-based view theory, firm resources are essential in improving performance (Wernerfelt 1984). The knowledge that the company gets through the research and development process can be in the form of company knowledge about consumers, or the company's position in the market, that can trigger the company to develop the right products and services that are acceptable to the market and increase the company's competitive advantages. Resources-based view theory also states that with a competitive edge, companies can improve performance. Ruiqi et al. (2017) found the positive effect of innovation on company performance in the future. The more innovation activities carried out will be able to improve company performance. Based on the description of the effect of innovation on company performance, the hypothesis that can be formulated is as follows:

\section{$\mathrm{H}_{2}$ : Innovation positively affects firm performance in the future.}

\section{The Effect of Gender on Board on Firm Performance}

Based on the upper echelon theory, the board of directors' characteristics is an element that deserves attention by the firm because it can form and predict company performance and choose strategies (Hambrick dan Mason 1984). The Board of Directors as an individual also has limitations and personal interests that can affect attitudes and behavior, ultimately affecting the company's performance (Nielsen 2010). One of the characteristics of directors that can affect company performance based on the upper echelon theory is gender.

According to the resources dependence theory, the board of directors is one of the resources owned by the company. The presence of women on the board of directors is a firm resource that can improve the company's relationship with the external environment (Goodstein et al. 1994). Women have a better understanding of consumers, the market and have a better ability to make decisions about company needs, as well as the ability to solve problems better than male directors (Goodstein et al. 1994; Arfken et al. 2004; Smith et al. 2006; Post and Byron 2015). In addition to increasing gender equality efforts, the presence of women on the board of directors of a company reflects the company's concern for gender equality. According to Oldford et al. (2020), companies that support gender diversity will have more women on the board of directors than companies that do not support gender diversity. The presence of women can enhance the company. Thus, it will improve company performance (Smith et al. 2006). In line with the research conducted by Duppati et al. (2020), they found that gender diversity as measured by the percentage of the number of female directors has a positive effect on company performance. Likewise, Tleubayev et al. (2020) also found a significant positive impact of female directors on company performance. Based on the description above, the hypotheses formulated is as follow:

\section{$\mathrm{H}_{3}$ : female director affects positively toward firm performance}

\section{Gender of Director's Effect toward Firm Performance through Innovation}

The female board of directors has a positive effect on innovation. Innovation is an activity conducted by companies that require creativity and innovative thinking. Women have an advantage over men in terms of knowledge and creativity, and diligence, which can oversee the company's innovation process (Adams and Ferreira 2009; Laguir and Den 
Besten 2016). The advantages possessed by women directors are in line with innovations that require creativity and diligence. Women's abilities and a better understanding of consumers and markets (Arfken et al. 2004) make innovations more targeted and advantageous.

The nature of female CEOs who are superior in terms of creativity and tend to carry out innovation activities will improve the company's quality in creating superior products. The products designed can make the company able to compete in business and win the market competition. Refers to resources-based theory (Wernerfelt 1984), a superior product will create a good company performance. Therefore, the hypothesis formulated is as follow:

\section{$\mathrm{H}_{4}$ : female directors affect firm performance through innovation}

\section{METHOD, DATA, AND ANALYSIS}

Criteria select the sample, those companies that carry out R\&D activities and are nonfinancial companies listed on the Indonesia Stock Exchange with the research period of 2009-2019. Thus, there were 237 samples. Hypothesis testing used multiple linear regression analysis, and it was conducted with SPSS tools. Furthermore, to obtain evidence whether there was an indirect effect of the mediating variable, the Process tool in SPSS was developed by Hayes (2017). This tool has an advantage over other mediation testing tools because besides producing output to analyze the influence of the independent variable on the dependent variable, it can also produce output that can provide an assessment of the mediating variable (Hayes 2017). In order to ensure that the test results of the independent variable on the dependent variable are not biased, a control variable is needed. The control variables used in this study were leverage, firm size, the board size, and firm age. Then this research uses models as follows in equation (1) and equation (2) :

$$
\begin{aligned}
& \text { Innovation }_{i, t+1}=\rho_{1} \text { FDir }_{i, t}+\rho_{2} \text { leverage }_{i, t}+\rho_{3} \text { FSize }_{i, t}+\rho_{4} \text { Bsize }_{i, t}+\rho_{5} \text { FAge }_{i, t}+\varepsilon_{i, t}(1) \\
& \text { performance }_{i, t+2}=\rho_{1} \text { FDir }_{i, t}+\rho_{2} \text { Ino }_{i, t+1}+\rho_{3} \text { lev }_{i, t}+\rho_{4} \text { FSize }_{i, t}+\rho_{5} \text { Bsize }_{i, t}+\rho_{6} \text { FAge }_{i, t} \varepsilon_{i, t}
\end{aligned}
$$

Where, FDir $=$ Female director, Ino $=$ innovation, leverage $=$ leverage FSize $=$ firm size, BSize $=$ board size, Fage $=$ Firm age. The dependent variable used in this research is firm performance. According to Kaur and Singh (2019) and Wang et al. (2016), company performance is measured by return on equity (ROE). Board gender and innovation affect the company's future performance because the output of innovation takes time to be recognized in the market, and it is implemented until it can have a positive impact on company performance, so company performance is measured one year after innovation is carried out and two years after the year of board leadership. ( $t+2)$ (Ruiqi et al. 2017; Tebourbi et al. 2020; McClelland et al. 2012).

\section{Independent Variable}

The independent variable in this study is the gender of the board of directors. The gender referred to in this female is the gender of the board of directors consisting of men and women. In this research, the gender of directors was measured by the percentage of female directors, namely the number of women on the board of directors divided by the number of directors (Tleubayev et al. 2020; Duppati et al. 2020). The mediating variable in this research was an innovation. Innovation is a process conducted by a company to develop new products, services, thoughts, and business processes (Kotler and Keller 2009). Based on Loukil et al. (2020), innovation is measured using R\&D expenditure divided by total assets. Innovation was measured in one year after the board of directors took office $(\mathrm{t}$ 
+1 ) because the directors' decisions for innovation require time to introduce organizational change (Loukil et al. 2020; Barker III and Mueller 2002). The equation variables showed in table 1.

Table 1. Operational Definitions

\begin{tabular}{|c|c|c|c|c|}
\hline & Variables & Definition & Equation & Sources \\
\hline \multirow[t]{2}{*}{ Dependent } & $\begin{array}{l}\text { Firm } \\
\text { Performance }\end{array}$ & $\begin{array}{l}\text { Company's profit } \\
\text { obtained as a result }\end{array}$ & net income & $\begin{array}{l}\text { Kaur and } \\
\text { Singh (2019) }\end{array}$ \\
\hline & & $\begin{array}{l}\text { of managing } \\
\text { resources which } \\
\text { include assets, } \\
\text { share capital, and } \\
\text { sales }\end{array}$ & $\overline{\text { shareholder equity }}$ & \\
\hline \multirow[t]{2}{*}{ Independent } & $\begin{array}{l}\text { Female } \\
\text { Directors }\end{array}$ & $\begin{array}{l}\text { The gender referred } \\
\text { to in this study is }\end{array}$ & number of female directors & $\begin{array}{l}\text { Duppati, Rao } \\
\text { et al. } 2020\end{array}$ \\
\hline & & $\begin{array}{l}\text { the gender of the } \\
\text { CEO, which } \\
\text { consists of men and } \\
\text { women }\end{array}$ & Total Directors & \\
\hline Mediating & Innovation & $\begin{array}{l}\text { A process carried } \\
\text { out by a company } \\
\text { to develop new } \\
\text { products, services, } \\
\text { thoughts, and } \\
\text { business processes }\end{array}$ & Total Asset & $\begin{array}{l}\text { Loukil, } \\
\text { Yousfi et al. } \\
\text { (2020) }\end{array}$ \\
\hline \multirow[t]{5}{*}{ Control } & Leverage & The level of debt & Total Debt & Sudana, 2015 \\
\hline & & corporate spending & Total Assets & \\
\hline & Board Size & $\begin{array}{l}\text { The number of } \\
\text { boards in the } \\
\text { company }\end{array}$ & Number of boards & $\begin{array}{l}\text { Kaur and } \\
\text { Singh (2019) }\end{array}$ \\
\hline & Firm Size & $\begin{array}{l}\text { Economies of scale } \\
\text { that the company } \\
\text { can enjoy }\end{array}$ & $\ln$ (total assets) & $\begin{array}{l}\text { Madugba, } \\
\text { Ben-Caleb et } \\
\text { al. } 2020\end{array}$ \\
\hline & Firm Age & $\begin{array}{l}\text { Life time of a } \\
\text { company since it } \\
\text { was founded. }\end{array}$ & $\begin{array}{l}\text { Research year - } \\
\text { establishment year }\end{array}$ & \\
\hline
\end{tabular}

\section{RESULTS}

Before testing the hypothesis, we did a descriptive analysis first. Table 2 shows the descriptive statistics of all variables used in the research. The statistical table shows that the maximum number of women on the board of directors was 1 . It means that directors in a company were entirely women, but this number does not indicate that women dominated directors in Indonesia. Based on the minimum score for the presence of women on the board of directors was 0 , and the average presence of women on the board of directors was only 0.1266864 , or around $13 \%$. It means that Indonesia had not fully practiced gender equality. It was reflected in the minimal presence of women on the board of directors. The second variable, innovation, has the minimum number was 0.00001 , and the maximum number was 0.20481 with an average of 0.0072106 . Based on these figures, it could be considered that companies in Indonesia were still making a little innovation using their assets, which was only $0.7 \%$ of the assets used for innovation. It is expected that firms in 
Indonesia will focus on increasing innovation efforts by utilizing existing assets. The dependent variable was a firm performance measured by accounting performance, such as return on equity (ROE) with a minimum value of -65.06 and a maximum value of 224.46.

Table 2. Descriptive Statistics

\begin{tabular}{lrrrrr}
\hline & $\mathbf{N}$ & Minimum & Maximum & Mean & Std. Deviation \\
\hline Gender BOD & 237 & 0 & 1 & 0.126686 & 0.187516 \\
Innovation & 237 & 0.00001 & 0.20481 & 0.007211 & 0.025044 \\
ROE & 237 & -65.06 & 224.46 & 15.21274 & 25.12186 \\
Leverage & 237 & 0.08379 & 0.914133 & 0.397836 & 0.210804 \\
Firm Size & 237 & 18.20933 & 31.64539 & 28.32823 & 2.664611 \\
Board Size & 236 & 4 & 21 & 10.50847 & 3.565188 \\
Valid N & 236 & & & & \\
(listwise) & & & & & \\
\hline
\end{tabular}

The control variables were leverage, firm size, and board size are also described in these statistics. Leverage had a minimum value of 0.08379 . It indicates that company funding was funded using debt that did not exceed $10 \%$. It means that several companies in Indonesia have not received tax benefits from the optimum use of debt, while the maximum value of leverage reaches 0.914133 . Maximum leverage reached a number close to 1. It illustrated that almost all firm's assets were funded by debt resulting in an increased corporate financial risk that could affect the company's decision to make risky investments. The size of the company shows that the size of the company in Indonesia was 28,328. Besides, the size of the board in Indonesia was about ten people.

Table 3. Correlations Analysis

\begin{tabular}{llllllll}
\hline & ROE & FDir & Leverage & FSize & BSize & FAge & Inovasi \\
\hline ROE & 1 & & & & & & \\
Gender on & $.185^{* * *}$ & 1 & & & & & \\
Board & $-.239^{* * *}$ & $-.121^{* *}$ & 1 & & & & \\
Leverage & $.179^{* * *}$ & $-.124^{* *}$ & $.085^{*}$ & 1 & & & \\
Firm Size & $.159^{* * *}$ & 0.065 & -0.018 & $.417^{* * *}$ & 1 & & \\
Board Size & $.297^{* * *}$ & $.238^{* * *}$ & $.104^{* *}$ & $.296^{* * *}$ & $.364^{* * *}$ & 1 & \\
Firm Age & $.488^{* * *}$ & $.212^{* * *}$ & $.152^{* * *}$ & $.102^{* *}$ & $.154^{* * *}$ & $.466^{* * *}$ & 1 \\
Inovasi & & & & & & \\
\hline
\end{tabular}

Table 3 shows the correlation between variables used to find the effect of female directors on company performance with innovation as a mediator. The correlation between variables had a small number. It indicates that there was no multicollinearity in the multivariate analysis. Table 2 shows that company performance as reflected by ROE had a relation with female directors (FDir), innovation, leverage, firm size (FSize), board size (BSize), and company age (FAge). This correlation shows that company performance was significantly affected by female directors, innovation, leverage, company size, the board size, and company age. Therefore, companies would tend to have board members consisting of at least one woman to improve the firm performance. 
Table 4. Multiple Regression Analysis

\begin{tabular}{lcc}
\hline & Gender on Board and Innovation & $\begin{array}{c}\text { Gender on Board, Innovation, } \\
\text { and Firm Performance }\end{array}$ \\
\hline Innovation & & $11.446^{* * *}$ \\
Gender on Board & $2.964^{* * *}$ & $(0.000)$ \\
Leverage & $(0.003)$ & 1.649 \\
& 1.604 & $(0.101)$ \\
Firm Size & $(0.018)$ & -1.340 \\
& 1.016 & $(0.182)$ \\
Board Size & $(0.310)$ & $2.075^{* *}$ \\
R square & 1.446 & $(0.039)$ \\
F Statistics & $(0.149)$ & -0.373 \\
& 0.074 & $(0.710)$ \\
Signis & 0.409 \\
& $0.4618^{* * *}$ & $31.795^{* * *}$ \\
\end{tabular}

Significance is shown by ***, and ${ }^{* *}$, which means significant at the $10 \%, 5 \%$, and $1 \%$ levels.

Table 4 presents multiple linear regression analysis results to test hypothesis 1 , hypothesis 2 , and hypothesis 3 . Table 4 column 2 is the result of the analysis to determine the effect of board gender on innovation. It is known that FDir had a coefficient of 0.122 and significant at $0.026(<0.05)$. Thus, hypothesis 1 was accepted, and H0 was not accepted. This means that female directors (FDir) had a significant positive effect on innovation. Other variables, leverage and company age (Fage), had an impact on innovation, while board size (Bsize) and firm size (FSize) had no significant impact on innovation. Table 3 column 3 is the result of the analysis to test hypotheses 2 and 3 . It is known that innovation had a coefficient of 0.491 and significant at the $1 \%$ level $(0.000<0.01)$. Thus, hypothesis 2 was accepted, and hypothesis 0 was not accepted. This means that innovation had a positive effect on company performance. An increase in innovation by 1 unit increases the company's performance by 0.491 . Female directors (FDir) have a coefficient of 0.049 and a significance of $0.334(>10 \%)$. Thus, hypothesis 0 was accepted, and hypothesis 3 was not accepted. It means that female directors had no positive effect on company performance.

Table 5. Mediating Analysis

\begin{tabular}{|c|c|c|c|c|c|c|}
\hline & \multirow{2}{*}{$\begin{array}{l}\text { Effect to } \\
\text { Innovation }\end{array}$} & \multirow[t]{2}{*}{$\begin{array}{l}\text { Direct Effect } \\
\text { To Firm } \\
\text { Performance }\end{array}$} & \multirow[t]{2}{*}{$\begin{array}{l}\text { Total Effect } \\
\text { To Firm } \\
\text { Performance }\end{array}$} & \multicolumn{3}{|c|}{$\begin{array}{c}\text { Indirect Effect } \\
\text { Gender on Board to Firm } \\
\text { Performance }\end{array}$} \\
\hline & & & & Effect & $\begin{array}{l}\text { Boot } \\
\text { LLC }\end{array}$ & $\begin{array}{l}\text { Boot } \\
\text { ULC }\end{array}$ \\
\hline $\begin{array}{l}\text { Gender on } \\
\text { Board }\end{array}$ & $\begin{array}{c}0.2460 \\
-0.0257\end{array}$ & $\begin{array}{c}0.0981 \\
-0.3342\end{array}$ & $\begin{array}{c}0.2188 \\
-0.0557\end{array}$ & 0.1207 & 0.0404 & 0.2056 \\
\hline Leverage & $\begin{array}{c}0.1238 \\
-0.0184\end{array}$ & $\begin{array}{c}-0.3257 \\
0.0000\end{array}$ & $\begin{array}{c}-0.2650 \\
0.0000\end{array}$ & & & \\
\hline Firm Size & $\begin{array}{l}-0.0210 \\
-0.7199\end{array}$ & $\begin{array}{l}0.1507 \\
0.0000\end{array}$ & $\begin{array}{c}0.1404 \\
-0.0216\end{array}$ & & & \\
\hline Board Size & $\begin{array}{l}-0.0003 \\
-0.9962\end{array}$ & $\begin{array}{l}-0.0064 \\
-0.9053\end{array}$ & $\begin{array}{l}-0.0063 \\
-0.9181\end{array}$ & & & \\
\hline Firm Age & $\begin{array}{l}0.4303 \\
0.0000\end{array}$ & $\begin{array}{c}0.0486 \\
-0.4056\end{array}$ & $\begin{array}{l}0.2597 \\
0.0000\end{array}$ & & & \\
\hline Innovation & & 0.4907 & & & & \\
\hline
\end{tabular}


Based on table 5 shows that the gender of the board of directors did not affect company performance. In contrast, the gender of the board of directors affected innovation, and innovation affects company performance. According to (Baron and Kenny 1986), In this condition, it can be considered that there was an indirect effect between the gender of the board of directors and company performance. Based on Hayes (2017), the indirect effect was tested using SPSS tools that produced the analysis results as described in table 4 . It can be seen that female directors had a positive effect on innovation but had no effect on firm performance. Based on the indirect effect shown in columns 6 and 7, it is known that the LLCI boot and ULCI boot were 0.0404 and 0.2056 , respectively, between bootLLCI and bootULCI, there was no value of 0 . Thus, it could be concluded that there was a mediating effect (Hayes 2017). Furthermore, hypothesis 4 was accepted. It means that innovation mediated the effect of the board of directors' gender on firm performance.

\section{DISCUSSION}

\section{The Effect of Gender on Board toward Innovation}

Hypothesis 1 of gender on board that had a positive effect on innovation was proven in this research. In line with research conducted by (Atallah et al. 2020; Torchia et al. 2018; Hernández-Lara and Gonzales-Bustos 2020), these results indicated that in Indonesia, the presence of women has a strong effect on firm' efforts to innovate. As stated by Alisjahbana in her book, Perempuan Pemimpin, women become good figures to lead companies in an era of innovation because of their characteristics, such as nurturing, participatory, and open to human resource development. The characteristics possessed by women will support the $R \& D$ team to develop products because they can provide some special advice and attention to the R\&D team, which in turn can make the company gain a competitive advantage.

\section{The Effect of Innovation toward Firm Performance}

This research found that innovation had a positive effect on firm performance. In line with research conducted by Ruiqi et al. (2017), they found the positive effect of innovation on firm performance. These results proved that the greater a firm's efforts to innovate, the company's performance would also increase. These results also supported the resourcebased view theory, which states that the company's performance would increase when the firm had a competitive advantage from its resources, such as the product (Wernerfelt 1984). Products are created or developed through an innovation process that can generate their advantages through fulfilling consumers' needs or create new needs that can later improve firm performance.

\section{The Effect of Gender onboard on Firm Performance}

This research found that gender on board did not affect company performance. These results contradicted Duppati et al. (2020) that found a positive impact of gender of the board of directors on firm performance. On the other hand, this research supports Amran et al. (2014) and Peni (2014) that did not find a significant effect between the gender of the board of directors on company performance. This insignificance could be due to the very minimal proportion of women in Indonesia, as explained in table 1. Thus, it is not strong enough to have a direct influence. In addition, CEO gender will not affect company performance when it has not made decisions that can affect company performance. Hence, it couldn't directly affect firm performance. 


\section{The Effect of Gender on Board toward Firm Performance through Innovation and Mediating Variable}

This research shows that gender on board affected firm performance through innovation. The results of this analysis answer the inconsistency of the results of the analysis of previous studies regarding the effect of gender on the board of directors on company performance. One of the reasons for this inconsistency is that it did not include innovation as the mediating variable. The board of directors is one of the organs in a company that can affect company performance. Still, based on process theory Markus and Robey (1988), the board of directors becomes an independent variable unable to provide immediate results. The board of directors will affect the company's performance through the decisions they made, one of which is innovation. Without decisions or actions they made, the board of directors would not have any effect, either on the firm performance.

\section{CONCLUSION, LIMITATIONS, AND SUGGESTIONS}

This research showed that the presence of women on the board of directors in firms in Indonesia does not have a positive effect on the performance of the firm they lead. These results are in line with research conducted by Amran et al. (2014), Dale-Olsen et al. (2012), Shukeri et al. (2012), Rose (2007) that the gender of the board of directors does not affect performance. The gender of the board of directors has a positive impact on innovation. In line with research Atallah et al. (2020), Torchia et al. (2018), and Hernández-Lara and Gonzales-Bustos (2020) in previous research, they found a significant positive effect between gender on the board of directors on innovation. These results prove that women with participatory leadership methods that emphasize human resource development can lead the firm to increase innovation activities. In addition, innovation has a positive influence on company performance. It is in line with the research by Ruiqi et al. (2017), and Tebourbi et al. (2020).

It supports the resource-based view Wernerfelt (1984) that company resources are to create competitive benefits that enable the company to improve performance, and one of the resources is the product. Products will be formed and developed through innovation activities. Based on these results, the gender of the board of directors does not have a direct effect on company performance, but rather indirectly through a variable, namely innovation as a mediation. The indirect effect of gender on the board of directors is supported by the results of data analysis using the process tools developed by (Hayes 2017).

We know that the number of women on the board of directors is still very minimal through this research. Almost all companies have no more than 50 percent women, even though, according to the existing laws and presidential regulations, Indonesia has supported gender equality. Because the results of this research indicate a positive influence on women's existence, the number of women on the board of directors needs to be increased. Especially in today's increasingly competitive industrial world, companies need consistent innovation to understand their company's position and make any improvements to create products that can increase their competitive advantage. Where in this study, these things are better done when the board of directors contains more women. 
As a country that supports gender equality through its regulations, Indonesia has a relatively small proportion of women on the board of directors. Then future research is expected to provide further research about the impact of the presence of women on the board of directors on firm performance by considering external factors or macroeconomic factors and regulations that support gender equality. Further research can compare with countries that have tighter or even looser gender equality regulations. Overall, this research contributes to assessing the role of women in company development and how women can bring companies to achieve competitive advantage and improve firm performance.

\section{REFERENCES}

Adams, R. B., and D. Ferreira. 2009. Women in the boardroom and their impact on governance and performance. Journal of financial economics 94 (2):291-309. https:// doi.org/10.1016/j.jfineco.2008.10.007

Amran, N. A., M. A. M. Yusof, R. Ishak, and N. Aripin. 2014. Do characteristics of CEO and chairman influence government-linked companies performance? Procedia-Social and Behavioral Sciences 109:799-803. https://doi.org/10/1016/j.sbspro.2013.12.546

Arfken, D. E., S. L. Bellar, and M. M. Helms. 2004. The ultimate glass ceiling revisited: The presence of women on corporate boards. Journal of Business Ethics 50 (2):177-186. https:/ / doi.org/10.1023/B:BUSI.0000022125.95758.98

Atallah, G., C. De Fuentes, and C. Panasian. 2020. Ownership, Compensation and Board Diversity as Innovation Drivers: A Comparison of US and Canadian Firms. Available at SSRN 3584949.

Barker III, V. L., and G. C. Mueller. 2002. CEO characteristics and firm R\&D spending. Management Science 48 (6):782-801.

Baron, R. M., and D. A. Kenny. 1986. The moderator-mediator variable distinction in social psychological research: Conceptual, strategic, and statistical considerations. Journal of personality and social psychology 51 (6):1173. https://doi.org/10.1037/00223514.51.6.1173

Bilimoria, D. 2006. The relationship between women corporate directors and women corporate officers. Journal of Managerial Issues:47-61.

Campbell, K., and A. Mínguez-Vera. 2008. Gender diversity in the boardroom and firm financial performance. Journal of Business Ethics 83 (3):435-451. https:// doi.org/10.1007/s10551-007-9630-y

Dale-Olsen, H., P. Schøne, and M. Verner. 2012. Chapter 7: Women on Boards of Directors and Firm Performance: Evidence from Denmark and Norway. Firms, Boards and Gender Quotas: Comparative Perspectives (Comparative Social Research, Volume 29), Emerald Group Publishing Limited:211-234. https://doi.org/10.1108/S01956310(2012)29 
Duppati, G., N. V. Rao, N. Matlani, F. Scrimgeour, and D. Patnaik. 2020. Gender diversity and firm performance: evidence from India and Singapore. Applied Economics 52 (14):1553-1565. https:/ / doi.org/10.1080/00036846.2019.1676872

Eagly, A. H. 2005. Achieving relational authenticity in leadership: Does gender matter? The leadership quarterly 16 (3):459-474. https:/ / doi.org/10.1016/j.leaqua.2005.03.007

Goodstein, J., K. Gautam, and W. Boeker. 1994. The effects of board size and diversity on strategic change. Strategic Management Journal 15 (3):241-250. https:// doi.org/10.1002/smj.4250150305

Hambrick, D. C. 2007. Upper echelons theory: An update: Academy of Management Briarcliff Manor, NY 10510.

Hambrick, D. C., and P. A. Mason. 1984. Upper echelons: The organization as a reflection of its top managers. Academy of management review 9 (2):193-206. https:// doi.org.10.2307/258434

Hayes, A. F. 2017. Introduction to mediation, moderation, and conditional process analysis: A regression-based approach: Guilford publications.

Hernández-Lara, A. B., and J. P. Gonzales-Bustos. 2020. The influence of family businesses and women directors on innovation. Applied Economics 52 (1):36-51. https:// doi.org/10.1080/00036846.2019.1638496

Jadiyappa, N., P. Jyothi, B. Sireesha, and L. E. Hickman. 2019. CEO gender, firm performance and agency costs: evidence from India. Journal of Economic Studies. https:// doi.org/10.1108/JES-08-2017-0238

Kaur, R., and B. Singh. 2019. Do CEO characteristics explain firm performance in India? Journal of Strategy and Management. https:/ / doi.org/10.1108/JSMA-02-2019-0027

Kotler, P., and K. L. Keller. 2009. Marketing management. 1. vyd. Praha: Grada, 2007, 788 s.

Laguir, I., and M. Den Besten. 2016. The influence of entrepreneur's personal characteristics on MSEs growth through innovation. Applied Economics 48 (44):4183-4200. https:// doi.org/10.1080/00036846.2016.1153792

Liu, C.-H. 2017. Creating competitive advantage: Linking perspectives of organization learning, innovation behavior and intellectual capital. International Journal of Hospitality Management 66:13-23. https:/ / doi.org/10.1016/j.ijhm.2017.06.013

Loukil, N., O. Yousfi, and S. B. Cheikh. 2020. Innovation Effort And Ceo'S Characteristics. International Journal of Innovation Management 24 (05):2050079. https:// doi.org/10.1142/S1363919620500796

Markus, M. L., and D. Robey. 1988. Information technology and organizational change: causal structure in theory and research. Management Science 34 (5):583-598. https:// doi.org/10.1287/mnsc.34.5.583 
McClelland, P. L., V. L. Barker III, and W.-Y. Oh. 2012. CEO career horizon and tenure: Future performance implications under different contingencies. Journal of Business Research 65 (9):1387-1393. https:/ / doi.org/10.1016/J.JBUSRES.2011.09.003

Naseem, M. A., J. Lin, R. ur Rehman, M. I. Ahmad, and R. Ali. 2019. Does capital structure mediate the link between CEO characteristics and firm performance? Management Decision.

Oldford, E., S. Ullah, and A. T. Hossain. 2020. A social capital view of women on boards and their impact on firm performance. Managerial Finance. https:// doi.org/10.1108/MF-02-2020-0091

Peni, E. 2014. CEO and chairperson characteristics and firm performance. Journal of Management \& Governance 18 (1):185-205. https:/ / doi.org/10/1007/s10997-012-92247

Post, C., and K. Byron. 2015. Women on boards and firm financial performance: A metaanalysis. Academy of Management journal 58 (5):1546-1571. https:// doi.org/10.5465/amj.2013.0319

Rose, C. 2007. Does female board representation influence firm performance? The Danish evidence. Corporate Governance: An International Review 15 (2):404-413. https:// doi.org/10.1111/j.1467-8683.2007.00570.x

Ruiqi, W., F. Wang, L. Xu, and C. Yuan. 2017. R\&D expenditures, ultimate ownership and future performance: Evidence from China. Journal of Business Research 71:47-54. https:// doi.org/10.1016/j.jbusres.2016.10.018

Shukeri, S. N., O. W. Shin, and M. S. Shaari. 2012. Does board of director's characteristics affect firm performance? Evidence from Malaysian public listed companies. International Business Research 5 (9):120. https:/ / doi.org/10.5539/ibr.v5n9p120

Smith, N., V. Smith, and M. Verner. 2006. Do women in top management affect firm performance? A panel study of 2,500 Danish firms. International Journal of productivity and Performance management. https://doi.org.10.1108/17410400610702160

Sofian, S., and H. Wijaya. 2020. Female in board and earnings management: Evidence in Indonesia non-financial firms. Jurnal Keuangan dan Perbankan 24 (4):449-462.

Tebourbi, I., I. W. K. Ting, H. T. M. Le, and Q. L. Kweh. 2020. R\&D investment and future firm performance: The role of managerial overconfidence and government ownership. Managerial and Decision Economics. https://doi.org/10.1002/mde.3173

Tleubayev, A., I. Bobojonov, T. Gagalyuk, and T. Glauben. 2020. Board gender diversity and firm performance: evidence from the Russian agri-food industry. International Food and Agribusiness Management Review 23 (1030-2020-236):35-54. https:/ / doi.org.10.22434/IFAMR2019.0011 
Torchia, M., A. Calabro, P. Gabaldon, and S. B. Kanadli. 2018. Women directors contribution to organizational innovation: A behavioral approach. Scandinavian Journal of Management 34 (2):215-224. https:/ / doi.org/10.1016/j.scaman.2018.02.0001

Wang, G., R. M. Holmes Jr, I. S. Oh, and W. Zhu. 2016. Do CEOs matter to firm strategic actions and firm performance? A meta-analytic investigation based on upper echelons theory. Personnel Psychology 69 (4):775-862. https:// doi.org/10.1111/peps.12140

Wernerfelt, B. 1984. A resource-based view of the firm. Strategic Management Journal 5 (2):171-180.

Zahra, S. A., and D. M. Garvis. 2000. International corporate entrepreneurship and firm performance: The moderating effect of international environmental hostility. Journal of business venturing 15 (5-6):469-492. https:// doi.org/10.1016/S0883-9026(99)000361 